\title{
Kebijakan Hukum Pidana Terhadap Kejahatan Cyber Bullying di Indonesia
}

\author{
Abdul Sakban' ${ }^{1}$, Sahrul ${ }^{2}$ Andi Kasmawati ${ }^{3}$ Heri Tahir ${ }^{4}$ \\ ${ }^{1}$ Pendidikan Pencasila dan Kewarganegaran, Universitas Muhammadiyah Mataram, Email: sakban.elfath@yahoo.co.id \\ ${ }^{2}$ Ilmu Hukum, Universitas Muhammadiyah Mataram, Email: sahrul25@gmail.com \\ ${ }^{3}$ Pendidikan Pancasila dan Kewarganegaraan, Universitas Negeri Makassar, Email: kasmawatiamri@yahoo.co.id \\ ${ }^{4}$ Pendidikan Pancasila dan Kewarganegaraan, Universitas Negeri Makassar, Email: heri.tahir@yahoo.co.id
}

INFO ARTIKEL
Riwayat Artikel:
Diterima: $26-$ September-
2019
Disetujui: $30-S e p t e m b e r-$
2019

\section{Kata Kunci:}

Kebijakan

Hukum

Pidana

Kejahatan

Cyber-bullying

\section{A. LATAR BELAKANG}

Kejahatan cyber-bullying merupakan tindakan abmoral yang dilakukan melalui media elektronik. Kejahatan ini membuat korban dikucilkan, dilecehkan, diadudomba, diintimidasi, mengancam, menyakiti/menghina harga diri orang lain sehingga menimbulkan permusuhan diantara mereka melalui

\begin{abstract}
Abstrak: Terjadinya kejahatan tersebut adalah kurangnya kontribusi penegak hukum dalam melakukan pengawasan dilingkungan sekolah, masyarakat, keluarga, dan diri pribadi dalam melakukan interaksi baik di media online maupun offline. Selain itu, kurangnya pemahaman aparat kepolisian dalam mengimplementasikan esensi Surat Edaran Hate Speech Republik Indonesia, Kitab Undang-Undang Hukum Pidana (KUHP). Tujuan yang akan dicapai dalam artikel ini adalah kebijakan hukum pidana terhadap kejahatan cyber-bullying di Indonesia, dan kebijakan hukum kriminal untuk era revolusi industri 4.0 dalam menyelesaikan kejahatan cyber-bullying. Penelitian ini menggunakan penelitian yuridis normative yang bersifat kualitatif. Pengumpulan bahan-bahan hukum dilakukan dengan mengidentifikasi dan menginventarisasi peraturan perundang- undangan, meneliti bahan pustaka, dan sumbersumber bahan hukum lainnya. Teknik analisis isu hukum (legal issue) dalam penelitian ini menggunakan logika berpikir campuran. Maksudnya penalaran (hukum) yang merupakan gabungan dari pola pikir induktif (inductive) dan deduktif (deductive) dalam persoalan hukum faktual yang konkrit. Hasil penelitian menunjukkan bahwa kebijakan hukum pidana dalam menyelesaikan kejahatan cyber-bullying dapat terapkan oleh aparat penegak hukum berupa KUHP dan Undang-Undang No. 8 Tahun 2018 tentang Informasi Teknologi Elektronik dengan melihat isi penjelasan pasal demi pasal dan konten kejahatan yang dilakukan oleh pelaku. Kebijakan hukum Pidana di era revolusi industry 4.0 tetap mengacu pada aturan yang berlaku di Indonesia.
\end{abstract}

Abstract: The occurrence of such crimes is the lack of law enforcement contributions in conducting supervision in school, community, family, and personal self in the interaction of both online and offline media. In addition, the lack of understanding of police officers in implementing the essence of circular Hate Speech of the Republic of Indonesia, the Criminal Code of Law (PENAL). The objectives to be achieved in this article are the policy of criminal law against cyber-bullying crimes in Indonesia, and the policy of criminal law for the era of the 4.0 industrial revolution in resolving cyber-bullying crimes. This research uses normative juridical research that is qualitative. The collection of legal materials is done by identifying and invarizing the legislation, examining the library materials, and other sources of legal materials. Technical analysis of legal issues in this study used mixed-thinking logic. It means reasoning (the law) which is a combination of inductive (inductive) and deductive mindset in the case of a concrete factual law. The results showed that criminal law policies in resolving cyber-bullying crimes could be applied by law enforcement officers in the form of penal CODE and law No. 8 year 2018 on electronic technology information by looking at the contents Article-by-article explanations and crime content committed by the perpetrator. The criminal Law policy in the 4.0 Industrial Revolution era continues to refer to the prevailing rules in Indonesia layanan internet dan teknologi mobile seperti halaman web dan grup diskusi serta telepon selular dan pesan teks (SMS).

Data kasus cyber bullying di Indonesia berdasarkan hasil laporan Liputan 6 [1] bahwa korban cyber bullying bahkan sampai bunuh diri akibat tekanan yang diterimanya melalui internet, kematian Yoga Cahyadi (36), yang melakukan tindakan nekat dengan 
menabrakkan dirinya ke kereta api di Yogyakarta pada Sabtu 26 Mei 2013 diduga karena tekanan dan hujatan akibat gagalnya acara musik Locstock Fest 2, dimana dia yang menjadi event organizer (EO)-nya. Hal itu tampak dari twit terakhirnya, "Trimakasih atas sgala caci maki @locstockfest2..ini gerakan..gerakan menuju Tuhan..salam". Senada juga Radar Pekalongan [2], melaporkan Sonya Depari, siswi cantik seorang model di Medan Sumatra Utara dibully habis-habisan di media sosial. Sonya Depari dibully lantaran mengaku anak jenderal dan mengancam seorang polisi wanita (Polwan) saat hendak ditilang karena melakukan konvoi saat usai melakukan ujian nasional. Sehari setelah dibully, Sonya Depari dikabarkan mengalami depresi dan tidak mau keluar rumah. Bahkan Ayah Makmun Depari Sembiring mendadak jatuh sakit dan langsung meninggal dunia.

Hasil penelitian menunjukkan bahwa sekitar $42 \%$ anak-anak mengalami cyber bullying, 35\% anak-anak diancam secara online, $58 \%$ anak-anak mengakui bahwa mereka sering mengalami pelecehan dan penghinaan secara online, dan $58 \%$ anak-anak itu mengakui bahwa mereka tidak melaporkan kepada orang tua mereka soal tindakan cyber bullying yang mereka alami[3]. Sehubungan dengan hal tersebut, cyber bullying merupakan tindakan yang dilakukan oleh seseorang atau sekelompok orang terhadap seseorang melalui text, gambar/foto, atau video yang cenderung merendahkan dan melecehkan[4]. Faktor kejahatan cyber bullying dapat dengan mudah terjadi karena ada rasa iri, tidak punya pencapaian, iseng, dan mempermalukan tanpa ketahuan. Beberapa faktor penyebab perilaku pelaku melakukan cyber-bullying yakni 1) faktor keluarga, faktor diri sendiri dan lingkungan juga memiliki tingkat pengaruh yang kuat dan signifikan. 2) pengaruh antara perlindungan digital, perlindungan sosial dan faktor diri sendiri juga berpengaruh pada perilaku korban[5].

Terjadinya kejahatan tersebut adalah kurangnya kontribusi penegak hukum dalam melakukan pengawasan dilingkungan sekolah, masyarakat, keluarga, dan diri pribadi dalam melakukan interaksi baik di media online maupun offline. Selain itu, kurangnya pemahaman aparat kepolisian dalam mengimplementasikan esensi Surat Edaran Hate Speech Republik Indonesia, Kitab Undang-Undang Hukum Pidana (KUHP) (Pasal 156, Pasal 157) untuk menjerat pelaku dugaan ujaran kebencian, dan Undang-Undang No.11 Tahun 2008 tentang Informasi dan Transaksi Elektronik. Dengan demikian kebijakan hukum pidana dapat memberikan dampak dan resolusi dalam memecahkan masalah kejahatan cyber-bullying di Indonesia.

Kebijakan hukum pidana terhadap kejahatan cyber bullying termuat dalam KUHP dan Undang-Undang Nomor 11 Tahun 2008 tentang Informasi dan Transaksi Elektronik, terdapat beberapa pasal yang berkaitan dengan bentuk cyberbullying terkait dengan pencegahan, penindakan maupun penuntutan kepada pelaku dan korban. Untuk itu pembaharuan KUHP dan Undangundang ITE dapat menjadi pedoman bagi aparat penegak hukum dalam menyelesaikan kejahatan cyberbullying di Indonesia [6].

Pendapat lainnya menjelaskan bahwa kebijakan kriminal dalam menanggulangi tindakan cyber bullying, sebaiknya perlu ada suatu peningkatan dan perubahan[7] sebagai berikut :

Pertama, dari segi kebijakan legislatif/formulasi/perundang-undangan di Indonesia yang akan datang, sebaiknya perlu ada konektifitas antara Sistem induk hukum pidana, yaitu KUHP dengan undang-undang di luar KUHP, artinya perlu dilakukan perubahan terhadap sistem induk KUHP Indonesia yang berlaku saat ini, agar sesuai dengan kondisi masyarakat Indonesia saat ini. Untuk itu Konsep KUHP secepatnya perlu disahkan. Disamping itu juga harus memperhatikan kajian komparatif terhadap undangundang di berbagai negara asing lainnya, yang terkait dengan tindakan cyber bullying agar lebih memaksimalkan dalam menanggulangi tindakan cyber bullying tersebut.

Kedua, dari segi kebijakan non penal yang akan datang dalam menanggulangi tindakan cyber bullying, sebaiknya perlu dilakukan peningkatan-peningkatan dari kebijakan non penal yang sudah dilakukan sebelumnya. Peningkatan tersebut dapat dilakukan dari berbagai segi pendekatan dan peranan, antara lain: Pendekatan Moral/Edukatif, Pendekatan Teknologi (Techno Prevention), Perananan Pemerintah, Peranan Media, dan Peranan Dunia Jurnalistik. Pendekatanpendekatan tersebut digunakan untuk dilakukan mulai dari keluarga, pemerintah, media massa untuk ikut serta membantu mencegah terjadinya kejahatan cyberbullying. Selepas dari itu, penelitian (Sakban, Sahrul, Kasmawati, \& Tahir, 2018) menjelaskan bahwa untuk mengurangi dan mencegah kejahatan cyberbullying di Indonesia, dapat dilakukan langkah-langkah berikut: 1) sosialisasi kepada lembaga pendidikan, instansi, kampus dan masyarakat secara rutin, 2) memaksimalkan perilaku etika berinternet, peran orang tua harus lebih intensif mengawasi anaknya dalam penggunaan media sosial, aparat sipil kepolisian rutin melakukan kampanye "anti bullying" (stop bully) di sekolah, kampus/instansi dan masyarakat, dan melibatkan organisasi social untuk mengawasi peredaran kejahatan cyber-bullying.

Dengan demikian artikel ini menjelaskan kebijakan hukum pidana terhadap kejahatan cyber-bullying di Indonesia dan kebijakan hukum kriminal untuk era industri 4.0 dalam menyelesaikan kejahatan cyberbullying di Indonesia..

Tujuan yang akan dicapai dalam artikel ini adalah kebijakan hukum pidana terhadap kejahatan cyberbullying di Indonesia, dan kebijakan hukum kriminal 
untuk era revolusi industri 4.0 dalam menyelesaikan kejahatan cyber-bullying.

\section{B. METODE PENELITIAN}

1. Jenis Penelitian

Memuat cara dan langkah dalam kegiatan untuk menjawab permasalahan penelitian. Terdiri dari (tulis dalam bentuk pointers):

2. Pendekatan

Penelitian ini menggunakan penelitian yuridis normative yang bersifat kualitatif, dengan penjelasan menggambarkan berbagai permasalahan kebijakan, alasan kebijakan, kejahatan cyberbullying di Indonesia [8].

3. Metode Pengumpulan Data

Pengumpulan bahan-bahan hukum dilakukan dengan mengidentifikasi dan menginventarisasi peraturan perundang- undangan, meneliti bahan pustaka (tulisan dan hasil karya ilmiah), dan sumber-sumber bahan hukum lainnya yang ada relevansinya dengan isu hukum dalam penelitian ini [9].

4. Teknik Analisa Data

Teknik analisis isu hukum (legal issue) dalam penelitian ini menggunakan logika berpikir campuran. Maksudnya penalaran (hukum) yang merupakan gabungan dari pola pikir induktif (inductive) dan deduktif (deductive) dalam persoalan hukum faktual yang konkrit. Proses yang terjadi dalam logika berpikir campuran adalah abstaksi (hukum), nilai-nilai hukum, asas-asas hukum konsep-konsep hukum, dan norma-norma hukum yang dirumuskan secara umum dalam aturan-aturan hukum positif, kemudian dikonkritisasi (dijabarkan) dan diterapkan guna penyelesaian persoalan hukum konkrit yang dihadapi, begitu juga seterusnya secara bolak-balik dalam proses campuran [10].

\section{HASIL DAN PEMBAHASAN}

\section{Kebijakan Hukum Pidana Terhadap} Kejahatan Cyber-Bullying di Indonesia

a. Kebijakan Legitimasi Hukum Pidana Terhadap Kejahatan Cyber-Bullying di Indonesia

1) Kitab Undang-undang Hukum Pidana Indonesia (KUHP)

Tindakan cyber-bullying jika dikaitkan dengan peraturan perundang-undangan yang ada di indonesia terkait dengan KUHP dapat dilihat beberapa pasal yang ada di dalam KUHP berhubungan dengan jenis-jenis cyber bullying adalah sebagai berikut :

Pasal 310 ayat 1 : Barang siapa sengaja menyerang kehormatan atau nama baik seseorang dengan menuduhkan sesuatu hal, yang maksudnya terang supaya hal itu diketahui umum, diancam karena pencemaran dengan pidana penjara paling lama sembilan bulan. Pasal tersebut menjelaskan tindakan cyber-bullying dalam bentuk Harrasment (tindakan menyiksa dengan menyerang terus menerus dan mengkritik)

Pasal 310 ayat $2:$ Jika hal itu dilakukan dengan tulisan atau gambaran yang disiarkan, dipertunjukkan atau ditempelkan di muka umum, maka diancam karena pencemaran tertulis dengan pidana penjara paling lama satu tahun empat bulan. Pasal tersebut berupaya mengidentifikasikan kejahatan tindakan cyber-bullying dalam bentuk Harrasment (tindakan menyiksa dengan menyerang terus menerus dan mengkritik)

Pasal 311 ayat 1 : jika yang melakukan kejahatan pencemaran atau pencemaran tertulis dibolehkan untuk membuktikan apa yang dituduhkan itu benar, tidak membuktikannya, dan tuduhan dilakukan bertentangan dengan apa yang diketahui, maka dia diancam melakukan fitnah dengan pidana penjara paling lama empat tahun. Pasal yang ini menjelaskan tindakan cyber bullying dengan bentuk Denigration (seseorang melakukan fitnah dengan berupaya menyebarkan kabar bohong).

Pasal 315 : Tiap-tiap penghinaan dengan sengaja yang tidak bersifat pencemaran atau pencemaran tertulis yang dilakukan terhadap seseorang, baik di muka umum dengan lisan atau tulisan, maupun di muka orang itu sendiri dengan lisan atau perbuatan, atau dengan surat yang dikirim atau diterimakan kepadanya, diancam karena penghinaan ringan dengan pidana penjara paling lama empat bulan dua minggu. Pasal ini menjelaskan tindakan cyberbullying dalam bentuk Harrasment (tindakan menyiksa dengan menyerang terus menerus dan mengkritik)

Pasal 369 ayat 1 : Barang siapa dengan maksud untuk menguntungkan diri sendiri atau orang lain secara melawan hukum, dengan ancaman pencemaran baik dengan lisan maupun tulisan, atau dengan ancaman akan membuka rahasia, memaksa seorang supaya memberikan barang sesuatu yang seluruhnya atau sebagian kepunyaan orang itu atau orang lain, atau supaya membuat hutang atau penghapusan piutang, diancam dengan pidana penjara paling lama empat tahun. Pasal tersebut menjelaskan kejahatan dalam bentuk Cyber Stalking. Cyber Stalking didefinisikan berupa "the act of threatening, harassing, or annoying someone through multiple e-mail messages, as through the internet, esp with the intent of placing the recipient in fear that an illegal act or an injury will be inflicted on the recipient or a member of the recipient's family or household."[11]. Jadi cyber stalking yang maksud adalah perbuatan tindakan mengancam, melecehkan, atau mengganggu seseorang melalui beberapa pesan e-mail, seperti melalui internet dengan maksud memposisikan penerima dengan 
merasa ketakutan melalui tindakan yang illegal dengan menyerang keluarga, lembaga dan subyek lainnya.

Dalam pasal-pasal tersebut mengatur pencemaran nama baik, tulisan dan atau gambar disampaikan di muka umum berupa fitnah, melakukan fitnah, tulisan bermotif menyinggungmaupun menyakiti orang lain.

2) Undang-undang No. 8 Tahun 2008 Tentang Informasi dan Transaksi Elektronik

Berdasarkan ketentuan pasal-pasal dalam Bab XI mengenai ketentuan pidana dalam UU ITE, maka dapat diidentifikasikan beberapa perbuatan yang dilarang (unsur tindak pidana) yang erat kaitannya dengan tindakan cyber bullying pada tiap-tiap pasalnya sebagai berikut :

Pasal 27 ayat 3 dengan unsur tindak pidana: mendistribusikan dan/atau mentransmisikan dan/atau membuat dapat diaksesnya informasi Elektronik dan/atau Dokumen Elektronik yang memiliki muatan penghinaan dan/atau pencemaran nama baik. Menjelaskan perilaku kejahatan aksi cyber bullying yang berbentuk cyber Harrasment (tindakan menyiksa dengan menyerang terus menerus dan mengkritik).

Pasal 27 ayat 4 dengan unsur tindak pidana: mendistribusikan dan/atau mentransmisikan dan/atau membuat dapat diaksesnya informasi Elektronik dan/atau Dokumen Elektronik yang memiliki muatan pemerasan dan/atau pengancaman. Menjelaskan perilaku cyber bullying yang berbentuk Cyber Stalking.

Pasal 28 ayat 2 dengan unsur tindak pidana : menyebarkan informasi yang ditujukan untuk menimbulkan rasa kebencian atau permusuhan individu dan/atau kelompok masyarakat tertentu berdasarkan atas suku, agama, ras, dan antargolongan (SARA). Pasal tersebut menjelaskan perilaku cyber-bullying yang berbentuk Cyber Harrasment (tindakan menyiksa dengan menyerang terus menerus dan mengkritik)

Pasal 29 dengan unsur tindak pidana : mengirimkan informasi Elektronik dan/atau Dokumen Elektronik yang berisi ancaman kekerasan atau menakut-nakuti yang ditujukan secara pribadi. Pasal tersbeut menjelaskan perilaku dan aksi cyberbullying yang berbentuk Cyber Stalking. Cyber stalking merupakan perbuatan tindakan mengancam, melecehkan, atau mengganggu seseorang melalui beberapa pesan e-mail, seperti melalui internet dengan maksud memposisikan penerima dengan merasa ketakutan melalui tindakan yang illegal dengan menyerang keluarga, lembaga dan subyek lainnya.

Pasal 30 ayat 1 dengan unsur tindak pidana : mengakses Komputer dan/atau Sistem Elektronik milik Orang lain dengan cara apa pun. Pasal tersebut menjelaskan perilaku dan aksi cyber-bullying yang berbentuk Impersonation. (meniru pribadi orang lain berupa gambar, atau gambar animasi dengan nuansa mengejek dan mengancam orang lain)

Pasal 32 ayat 2 dengan unsur tindak pidana : memindahkan atau mentransfer Informasi Elektronik dan/atau Dokumen Elektronik kepada sistem Elektronik Orang lain yang tidak berhak. Pasal tersebut menjelaskan tentang aksi dan tindakan cyber-bullying yang berbentuk Outing and Trickery. (menyebarkan rahasia orang lain, atau foto-foto pribadi orang lain. Sedangkan trickey adalah tipu daya, membujuk seseorang dengan tipu daya agar mendapatkan rahasia atau foto pribadi orang tersebut).

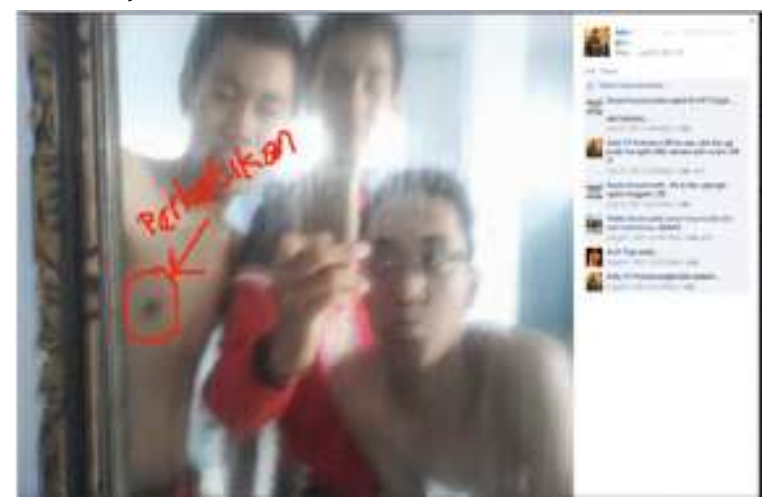

Gambar 1. Foto perilaku Outing and Trickery

3) Surat Edaran Kepolisian Republik Indonesia tentang Hate Specch

Berdasarkan ketentuan Surat Edaran Kepolisian Republik Indonesia dalam ketentuan pidana tentang Ujaran Kebencian, maka dapat diidentifikasikan beberapa perbuatan yang dilarang (unsur tindak pidana) yang erat kaitannya dengan tindakan cyber bullying pada tiap-tiap poinnya sebagai berikut :

Pada f, bahwa ujaran kebencian dapat berupa tindak pidana yang diatur dalam Kitab Undang-Undang Hukum Pidana (KUHP) dan ketentuan pidana lainnya di luar KUHP, yang berbentuk antara lain:

a) penghinaan;

b) pencemaran nama baik;

c) penistaan;

d) perbuatan tidak menyenangkan;

e) memprovokasi;

f) menghasut;

g) penyebaran berita bohong;

h) dan semua tindakan di atas memiliki tujuan atau bisa berdampak pada tindak diskriminasi, kekerasan, penghilangan nyawa, dan/atau konflik social.

Selanjutnya, bahwa ujaran kebencian sebagaimana dimaksud di atas, bertujuan untuk menghasut dan menyulut kebencian terhadap individu dan/atau kelompok masyarakat dalam berbagai komunitas yang dibedakan dari berbagai aspek. 
b. Upaya Represif Police dalam Menyelesaikan Kejahatan Cyber-Bullying

Upaya represif polisi merupakan salah satu cara penindakan dalam upaya penyelesaian kejahatan cyberbullying dengan mengacu pada Standar Operasional Prosedur (SOP) yang dimiliki oleh Kepolisian Republik Indonesia dalam menyelesaikan kejahatan pidana. Dengan demikian berikut cara penyelesaian kejahatan cyber-bullying di Indonesia.

Alur penyelesaian cyber-bullying yang digunakan oleh Kepolisian Daerah Nusa Tenggara Barat adalah melalui langkah-langkah berikut ini: 1) Korban CyberCrime lapor ke polisi; 2) Laporan diterima Sentral Pelayanan Kepolisian (SPK); 3) Lapor di Disposisi Polisi piket; 4) Laporan diterima Bin opsional di register; 5) Kabsubdit Cyber-crime/Penyidik; 6) Kanit/Tim penyidik; 7) Penilaian Laporan selama 3 hari: 8) Penyidik membuat SP2HP; 9) Jawaban Laporan[12]. Sementara metode represif yang diujicobakan oleh peneliti mengikuti tahapan-tahapan berikut 1) Korban Cyberbullying lapor ke polisi; 2) Laporan diterima Sentral Pelayanan Kepolisian (SPK); 3) Lapor di Disposisi Polisi piket; 4) Laporan diterima Bin opsional di register; 5) Kabsubdit Cyber-crime/Penyidik; 6) Kanit/Tim penyidik; 7) Penilaian Laporan selama 3 hari: 8) Penyidik membuat SP2HP; 9) Jawaban Laporan; 10) Persidangan; 11) Penetapan Sanksi Pidana. Langkah-langkah penyelesaian kasus tersebut sangat membantu polisi untuk menuntaskan kejahatan cyber-bullying dan memberikan dampak yang positif terhadap peningkatan kinerja kepolisian dalam menyelesaikan kejahatan cyber-bullying.

Dalam penyelesaian cyber-bullying dibantu juga oleh integrasi lembaga penegak hukum lain diantaranya Kepolisian Daerah Nusa Tenggara Barat Kasubdit Direktur Reses Kriminal Khusus Cyber-Crime, Kementerian Informasi dan Teknologi Republik Indonesia, PT. Telkom Cabang Nusa Tenggara Barat dan Pengadilan Tinggi Nusa Tenggara Barat telah melaksanakan tugas dan kewenangannya masingmasing sesuai dengan undang-undang yang berlaku di Indonesia khusus penindakan kejahatan cyber-bullying. Adapun tugas Kepolisian Daerah Kasubdit Direktur Reses Kriminal Khusus Cyber-Crime dalam menyelesaikan kejahatan cyber-bullying adalah meregistrasi laporan cyber-bullying, mengecek laporan korban, melakukan penyelidikan, menilai laporan selama minimal 3 maksimal 7 hari, menerbitkan SP2HP, menetapkan tersangka dan menyerahkan kasus cyberbullying ke pengadilan. Kementerian Informasi dan Teknologi Republik Indonesia Direktorat Jenderal Aplikasi Informatika bertugas untuk memblokir akunakun bernilai negative, penipuan, kejahatan dan bisnis online setiap hari. Tujuan untuk menghindari konflik dan penyebaran kejahatan tidak meluas, membantu kepolisian dalam proses penyelidikan, selain itu melakukan sosialisasi dalam menggunakan aplikasi teknologi informatika yang sehat dan menyenangkan hati masyarakat. Demikian juga peran PT. Telkom Cabang Nusa Tenggara Barat membantu kepolisian dalam proses penyelidikan untuk mengetahui sumber asli pelaku cyber-bullying.

Pengadilan Tinggi Nusa Tenggara Barat atau Pengadilan Negeri Kota/Kabupaten berperan memberikan sanksi pidana setelah melalui proses peradilan mulai pembacaan tuntutan, pembelaan, dan pembacaa keputusan hakim sebagai dengan tindak pidana cyber-bullying. Hal tersebut sejalan dengan pendapat yang menemukan bahwa koordinasi antara lembaga pemerintahan dalam menyelesaikan konflik apapun sangat diperlukan seperti ketua rukun rumah tangga, kepala lingkungan, kecamatan, polsek, pemangku adat sangat diperlukan dalam menyelesaikan konflik komunal untuk mengetahui pelaku utama [13]. Demikian juga Priyatno menjelaskan penegakan hukum pidana in concreto melalui restorative justice dapat dilakukan dengan kegiatan-kegiatan[14]. Pertama, Lembaga Pemasyarakatan, Sektor Kepolisian, Jaksa dan Hakim diberikan kewenangan dalam menyelidiki, memutuskan kejahatan sesuai dengan muatan pelanggarannya. Kedua, kewajiban aparat hukum (polisi, jaksa dan hakim) melaksanakan creation, extrinction, atau alternation of primary rules dalam menyelesaikan kejahatan pidana untuk saling berkoordinasi untuk penyungkapan pelaku dan korban kejahatan.

Selama pelaksanaan metode represif menghasilkan dampak positif dan dampak negatif. Dampak positif digunakan metode represif untuk penyelesaian kejahatan cyber-bullying adalah kejahatan cyberbullying dapat selesaikan dengan transparan, akuntabel, tepat dan objektif, tidak semua laporan masyarakat dapat di proses karena kekurangan alat bukti namun hanya laporan yang dinyatakan lengkap dilakukan penyelesaian hingga tuntas, metode represif sangat membantu polisi dalam menyelesaikan kasus cyber yang kompleks dengan dibantu beberapa lembaga penegakan hukum dan pemerintah, jumlah kasus yang telah dihasilkan melalui metode represif mencapai $85,12 \%$. Terciptanya hubungan lembaga penegak hukum dan pemerintah daerah maupun perusahaan telekomunikasi dalam menangani kejahatan cyber-bullying secara integrasi, untuk mencegah kejahatan cyber-bullying pemerintah untuk selalu memberikan sosialisasi pada lembaga pendidikan untuk mengampanyekan stop bullying. Dampak negatif adalah alat pembuktian sangat sulit ditelusuri secara tuntas karena akun maupun identitas pelaku berganda dan anonym sehingga penyidik kesulitan mendapatkan bukti otentik.

\footnotetext{
2. Kebijakan Hukum Kriminal Untuk Era Revolusi Industri 4.0 dalam Menyelesaikan Kejahatan Cyber-Bullying di Indonesia
} 
Media social merupakan salah satu media yang sangat mudah untuk mempengaruhi orang lain dengan berbagai pesan, ucapan, gambar yang berkonten negative, melecehkan, mengintimidasi, memecah belah dengan tanpa sengaja mengejak namun kalimat yang diucapkan bermotif kejahatan. Indonesia merupakan salah satu Negara pengguna media social sangat tinggi mencapai 88,1 juta jiwa, sehingga rawan terjadinya kejahatan, berdasarkan hasil studi menunjukkan bahwa ada berbagai kejahatan yang dilakukan oleh masyarakat Indonesia melalui media masa diantaranya, yaitu: pencemaran nama baik, penghinaan, ujaran kebencian dan cyber-bullying[15]. Selain itu era revolusi industry 4.o ini terjadi pergeseran komunikasi masyarakat yang awalnya untuk menyampaikan pesan singkat namun sekarang komunikasi di media social berubah alat penyampaian informasi bernuansa negative, mencemarana nama baik, membuly orang baik menyangkut individu, lembaga, jabatan dan instansi.

Terkait dengan hal tersebut, kebijakan hukum kriminal terhadap kejahatan di era revolusi industry 4.0 berupa kejahatan cyber-bullying, pencemaran nama baik dan kejahatan di media sosial dapat mengacu pada Kitab Umum Hukum Pidana (KUHP) dan Undang-Undang No. 11 Tahun 2008. Dalam Kitab Umum Hukum Pidana (KUHP) dan Undang-undang tersebut telah mengatur segala larangan, perbuatan, etika menggunakan alat kumonikasi, kegunaan telekomunikasi dan penjelasan hukuman dan sanksi pidana, namun belum mengatur secara spesifik tentang kejahatan cyber-bullying. Termasuk KUHP 2015 dalam bab 8 Buku Kedua Bagian kelima, dalam paragraf kesatu sampai dengan paragraf kedua mengatur tentang tindakan yang menyebabkan kerusakan sistem elektronik yang digunakan pemerintah dalam tujuan pertahanan, sedangkan bab ketiga membahas tentang pornografi anak melalui komputer. Kedua bab tersebut tidak menjelaskan kejahatan cyberbullying [7]. Dengan demikian kebijakan hukum pidana terhadap kejahatan cyber-bullying sangat dibutuhkan untuk mengontrol kejahatan di era revolusi industry 4.o.

Adapun rencana kebijakan hukum kriminal untuk era revolusi industri 4.0 dalam menyelesaikan kejahatan cyber-bullying di Indonesia adalah sebagai bserikut:

a. Melakukan revisi KUHP terkait kejahatan cyber bullying;

b. Menambahkan pasal yang mengatur dan menjelaskan kejahatan cyber-bullying;

c. Membuat regulasi antara lembaga aparat penegak hukum seperti Kepolisian daerah, kementerian Informasi dan teknologi republic Indonesia, kantor Telkom, lembaga pendidikan, kampus, dan instansi.

Hal tersebut dapat juga dilakukan berupa tindakan pencegahan kejahatan komputer dapat dilakukan dengan meningkatkan system pengamanan komputer, Khususnya pada serangan hacker atau pun virus. Secara umum kejahatan komputer dapat dicegah melalui faktor-faktor lingkungan [16]yaitu:

a. Pendidikan komputer sejak dini yang dimulai dari bangku sekolah, sehingga dapat meningkatkan pengetahuan dan kesadaran atas bentuk-bentuk perbuatan dalam menggunakan sarana computer yang salah.

b. Pengawasan terhadap warnet-warnet yang ada di masyarakat, untuk mencegah warnet sebagai sarang penggunaan situs yang melanggar hukum.

c. Pengawan orang tua terhadap anak pengguna komputer dan internet.

d. Membuat wadah bagi anak-anak yang memiliki kelebihan dibidang jaringan internet.

e. Filterisasi situs-situs yang merusak norma anak muda oleh pemerintah.

f. Sanksi yang tegas bagi pemilik warnet jika tidak menegur users nya yang sedang menggunaan situs cyber gambling, cyberporn, dll.

g. Banyaknya komunitas black hat (hacker hitam) di Indonesia sebagai salah satu dampak penyebab maraknya terjadi kejahatan di dunia maya, lemahnya system computer, dan begitu kecilnya gaji para ahli IT di Indonesia menyebabkan para master computer berbuat criminal demi mencukupi kebutuhan financialnya, jadi perlu peningkata taraf hidup bagi para ahli IT.

Selain itu, kebijakan hukum pidana terhadap kejahatan cyber sangat penting dilakukan, karena pembaharuan kebijakan hukum pidana dalam rangka penegakan hukum terhadap cyber crime ataupun cyber bullying dapat mempertimbangkan konvensi-konvensi internasional dan pengaturan penegakan hokum kejahatan cyber di Negara-negara lain untuk menciptakan sinkronisasi aplikasi penegakan hukum[17] Dengan demikian kebijakan hokum pidana dalam menyelesaikan kejahatan cyber-bullying di era revolusi industry 4.0 tetap mengacu pada KUHP dan Undangundang No. 11 tahun 2008 serta kejahatan lintas Negara dapat digunakan konvensi-konvensi internasional.

\section{KESIMPULAN}

Kebijakan hukum pidana dalam menyelesaikan kejahatan cyber-bullying dapat terapkan oleh aparat penegak hukum berupa KUHP dan Undang-Undang No. 8 Tahun 2018 tentang Informasi Teknologi Elektronik dengan melihat isi penjelasan pasal demi pasal dan konten kejahatan yang dilakukan oleh pelaku. Kebijakan hukum Pidana di era revolusi industry 4.0 tetap mengacu pada aturan yang berlaku di Indonesia. 


\section{UCAPAN TERIMA KASIH}

Tim peneliti mengucapkan terima kasih kepada Kemenristekdikti RI, LPPM Universitas Muhammadiyah Mataram, Peneliti di Universitas Negeri Makssar, dan semua pihak yang telah banyak membantu dalam penyelesaikan penelitian ini.

\section{DAFTAR RUJUKAN}

[1] Liputan6, "6 Korban Cyberbullying yang Berakhir Bunuh Diri," Www.Liputan6.Com. 2013.

[2] Radar Pekalongan, "6 Kasus Bully Berujung Kematian.” Radar Pekalongan Berita Harian. (Online), 2016.

[3] A. Septi, "Cyber Bullying," Catatan Ilmu, 2014.

[4] M. Hidajat, A. R. Adam, M. Danaparamita, and S. Suhendrik, "Dampak Media Sosial dalam Cyber Bullying," ComTech Comput. Math. Eng. Appl., vol. 6, no. 1, pp. 72-81, 2015.

[5] M. M. Pandie and I. T. J. Weismann, "Pengaruh Cyberbullying di Media Sosial terhadap perilaku reaktif sebagai pelaku maupun sebagai korban cyberbullying pada siswa kristen SMP Nasional Makassar," J. Jaffray, vol. 14, no. 1, pp. 43-62, 2016.

[6] F. C. SAT, E. Soponyono, and A. M. E. S. Astuti, "Kebijakan Hukum Pidana dalam Upaya Penanggulangan Cyberbullying dalam Upaya Pembaharuan Hukum Pidana," Diponegoro Law J., vol. 5, no. 3, pp. 1-21, 2016.

[7] W. F. Frensh, S. Kalo, M. Mulyadi, and C. Bariah, "Kebijakan Kriminal Penanggulangan Cyber Bullying terhadap Anak sebagai Korban," USU Law J., vol. 5, no. 2, 2017.

[8] P. Mahmud Marzuki, "Penelitian Hukum," Jakarta: Kencana Prenada Media, 2015.

[9] I. M. P. Diantha and M. S. SH, Metodologi penelitian hukum normatif dalam justifikasi teori hukum. Prenada Media, 2016.

[10] M. Marzuki, Penelitian Hukum: Edisi Revisi. Prenada Media, 2017.

[11] R. M. Mersky and J. Price, "The Dictionary and the Man: The Eighth Edition of Black's Law Dictionary, Edited by Bryan Garner," Wash. Lee Law Rev., vol. 63, no. 2, p. 719, 2006.

[12] D. Daryono and B. Sugiantoro, "Pengembangan Framework Pelaporan Cyber Crime," JISKA (Jurnal Inform. Sunan Kalijaga), vol. 1, no. 3, pp. 133-147, 2017.

[13] M. Natsir, "Violent Actions in North Cakra, Mataram, West Nusa Tenggara Indonesia," J. Leg. Ethical Regul. Issues, vol. 20, no. 1, pp. 1-7, 2017.

[14] D. Priyatno, "The Alternative Model of Corporate Criminal Sanction Management in Indonesia," $J$. Leg. Ethical Regul. Issues, 2017.

[15] A. Sakban, S. Sahrul, A. Kasmawati, and H. Tahir, "The Role of Police to Reduce and Prevent Cyberbullying Crimes in Indonesia," in 1st International Conference on Indonesian Legal Studies (ICILS 2018), 2018.

[16] P. Angkupi, "Kejahatan Melalui Media Sosial Elektronik Di Indonesia Berdasarkan Peraturan Perundang-Undangan Saat Ini," MIKROTIK $J$. Manaj. Inform., vol. 2, no. 1, 2017.

[17] S. H. Azizurrahman, "Pembaharuan Kebijakan
Penegakan Hukum Pidana di Era 'Cyber," Masal. Huk., vol. 41, no. 2, pp. 298-305, 2012. 